\title{
Is there a Logical Integration Sequence After EMU?
}

\author{
Patrick M. Crowley \\ Texas A \& M University
}

\begin{abstract}
In this paper the Balassa steps of economic integration are first reviewed, and then extended to cover currernt integration configurations. Pre-conditions for each stage of integration are detailed using a backward-looking economic conditionality approach, and then both economic and political spillover effects are analysed within a forward-looking approach so as to evaluate the sequencing of steps of integration. The European Union (EU) is currently the most advanced from of regional integration, so the template is then applied to the EU. The main findings are that fiscal union does not need to occur directly after Economic and Monetary Union (EMU), but rather a dynamic that attains political union first and then attains fiscal union might be preferable, dependent on whether EMU forms an optimal currency area or not.
\end{abstract}

- JEL classifications: F10, F15, F30, F42

- Key words: Process of integration, Europe, Economic integration, Monetary integration

\section{Introduction}

Now that European Economic and Monetary Union (EMU) is in operation, policymakers have been starting to question and propose measures that would further integrate the EU. There is little to guide either the theoretician or the policymaker as to any "natural" sequence for regional integration post-EMU. The theoretical

\footnotetext{
*Corresponding address: Patrick M. Crowley, College of Business, Texas A \& M University- Corpus Christi, 6300 Ocean Drive, Corpus Christi, TX 78412, USA. Tel: +1-361-825-6011, Fax: +1-361-8255609, E-mail: Patrick.Crowley@cob.tamucc.edu. (C2006-Center for International Economics, Sejong Institution, All Rights Reserved.
} 
template most social scientists think of when referring to regional integration is in fact a template usually referred to as the "Balassa stages of integration" after Balassa (1961). But this template focused on the earlier stages of integration, given that in the middle of the last century Europe was only just beginning the integration process; since then there has been little attention given to the sequencing of the later stages of integration. In terms of the behaviour of the EU supranational agencies, there appears to be no clear preference for any particular integration dynamic post-EMU either. At this stage, this may have more to do with the natural tendency to focus on the problems associated with EU enlargement rather than any purposeful neglect of the issue.

Given this backdrop, this paper asks "what next?" in terms of further integration for the EU. As EMU is unprecedented, to effectively answer this question we need to take a look at the whole theoretical integration template and the possible dynamics that can arise from the template, and clearly not just those experienced by the EU. The Balassa stages of regional integration are outlined and analysed and then used as a theoretical launch-pad for a review of the economic integration process. This then allows: a) an analysis of the possible integration paths that the EU might take beyond EMU; and then b) an answer to the question of whether there is any logical or superior sequencing to the next stages of economic integration in the EU.

Following a review and analysis in section 2, section 3 applies the framework to the EU at its current stage of economic integration and looks at the various options the EU has for further integration. Section 4 concludes.

\section{The Theory and Nature of Regional Integration}

Balassa's five stages of economic integration (Balassa (1961)) constituted a free trade area, customs union, common market, economic union and total economic integration. As Laffan, O'Donnell and Smith (2000) note, Balassa's view of a common market underestimated the amount of positive integration necessary in practice, and similarly overestimated the amount of centralisation necessary for an economic union or monetary union. In fact Balassa's vision of total economic integration coincided with a federation or confederation, so could not have envisaged the European Union as we now know it. Balassa's stages have since been expanded and now usually include the following steps: free trade area, customs union, common market, economic union, monetary union and political union (see Molle 
(1997) for example). Even this is not a complete sequencing of the actual stages of economic union, as fiscal union or some kind of fiscal arrangement (such as the Stability and Growth pact) does not fit into this taxonomy.

Table 1 presents an extended version of the Balassa process, with examples at each stage of economic integration - these examples reflect countries that have been in such a situation, or are currently in such a situation.

Several things are noteworthy about the table. First there is an implicit assumption in the literature and in the way that most academics read the table that the levels of economic integration imply a sequential process. Strictly speaking, this is not the case. The first two levels of integration, A and B, relate only to trade in goods and services, and either can be used as a basis for further integration to a common market. So for example, NAFTA is not a customs union, but there is no theoretical reason why the regional trade agreement cannot skip the customs union stage and become a common market or a monetary union, or economic union for that matter.

Table 1. Extended Balassa Stages of Economic Integration

\begin{tabular}{|c|c|c|c|}
\hline $\begin{array}{l}\text { Level of } \\
\text { integration }\end{array}$ & Description & Characteristics & Examples \\
\hline 0 & Regional autarky & - bilateral trade agreements & Japan (before ASEAN) \\
\hline A & FTA & $\begin{array}{l}\text { - tariffs and quotas removed } \\
\text { internally } \\
\text { - national tariffs retained against } \\
\text { outside }\end{array}$ & NAFTA \\
\hline B & Customs union & $\begin{array}{l}\text { - tariffs and quotas removed } \\
\text { internally } \\
\text { - common external tariff }\end{array}$ & Mercosur \\
\hline $\mathrm{C}$ & Common market & $\begin{array}{l}\text { - free movement of factors of } \\
\text { production, goods and services }\end{array}$ & EU (before EMU) \\
\hline $\mathrm{D}$ & Economic union & $\begin{array}{l}\text { - harmonization or coordination of } \\
\text { some national policies } \\
\text { - transfer of some policies to } \\
\text { supranational level }\end{array}$ & $\begin{array}{l}\text { Competition policy in } \\
\text { the EU }\end{array}$ \\
\hline $\mathrm{E}$ & Monetary union & $\begin{array}{l}\text { - single currency } \\
\text { - single central bank }\end{array}$ & $\mathrm{ECB}$ in the $\mathrm{EU}$ \\
\hline $\mathrm{F}$ & Fiscal union & $\begin{array}{l}\text { - harmonization of taxes } \\
\text { - fiscal sovereignty }\end{array}$ & \\
\hline G & Political union & $\begin{array}{l}\text { - effective and democratic body at } \\
\text { supranational level }\end{array}$ & $\begin{array}{l}\text { Does not exist out of a } \\
\text { regional integration } \\
\text { project }\end{array}$ \\
\hline
\end{tabular}

Note: $\mathrm{E}$ and $\mathrm{F}$ are actually interchangeable, as for example various authors place these two levels of integration in different orders (see Molle (1997) and contrast with the order of chapters in Robson (1998)) 
But note that a common market (C) does imply either A or B, but a monetary union does not necessarily imply any other stages of integration either. Indeed, dollarization in countries like Ecuador and Panama represents a form of monetary union, but that does not necessitate an elimination of tariffs and quotas with the United States. Even in the context of a regional trade agreement such as NAFTA, instituting a monetary union does not imply a common market, economic union or a customs union.

It is also apparent that new "models" of integration are now emerging. Three examples are: i) the Central and South American countries where Ecuador and Panama have opted for full blown dollarization, and where Argentina maintained a currency board against the US dollar during the $1990 \mathrm{~s}^{1}$; ii) the EU, where the Central and Eastern European countries (CEEC) are expected to be able to assimilate into EMU after only two years, but they have not been allowed full membership of the common market (labour movements have been restricted for a considerable period of time); and iii) the African Union (AU), which was formed in 2002 largely in the mould of the EU, but incorporates seven existing regional economic agreements, an umbrella African Economic Community (AEC) and ambitious plans to launch African monetary union at some point in the future. All these examples clearly imply the emergence of different integration dynamics - one in the context of autonomous decision-making within countries in relation to their external affairs, the next with regard to collectively-decided rules for membership in an existing regional integration agreement, and the third an emergent all-encompassing multilayered continental organization.

So are there any pre-conditions for any given form of regional integration? The sequence of regional integration, taking a backwards-looking view of integration is described in table 2 below.

Table 2 highlights several issues. First, it suggests that there are few pre-conditions, in theory, for adoption of any of the given stages of integration. Second, the table illustrates that certain levels of integration, notably a common market (C) and the political union (G) imply prior "stages" of integration have been accomplished. Clearly a common market, defined as an area where all factors of production, goods and services can move freely implies that goods and services can move across borders without restraint ${ }^{2}$. Likewise, a political union implies that the parliament or government

${ }^{1}$ In the constexts of Central America Free Trade Agreement (CAFTA), this implies a different level of intetration with the US than for the NAFTA bloc, and thus will likely imply a different dynamic for these two trade blocs going forward. 
Table 2. Pre-Conditions for Economic Integration

\begin{tabular}{|c|c|c|c|}
\hline Level of integration & Description & Dependent upon & Examples \\
\hline $\mathrm{C}$ & Common market & $\begin{array}{l}\text { A or B (necessary, } \\
\text { between but not within) }\end{array}$ & $\begin{array}{l}\text { EU or NAFTA (not for all } \\
\text { factors) }\end{array}$ \\
\hline $\mathrm{D}$ & Economic union & None (necessary) & Competition policy in the EU \\
\hline $\mathrm{E}$ & Monetary union & None (necessary) & $\begin{array}{l}\text { German reunification } \\
\text { WAMU } \\
\text { Hawaiian adoption of the } \\
\text { US\$ }\end{array}$ \\
\hline $\mathrm{F}$ & Fiscal union & $\begin{array}{l}\text { None (necessary for } \\
\text { harmonisation) } \\
\text { G (sufficient for fiscal } \\
\text { sovereignty) }\end{array}$ & EU to some degree \\
\hline G & Political union & F (necessary) & $\begin{array}{l}\text { Switzerland } \\
\text { USA } \\
\text { Canada }\end{array}$ \\
\hline
\end{tabular}

has some fiscal sovereignty, so some form of fiscal union is desirable as a prerequisite. Interestingly though, a political union does not imply that a monetary union has occurred - there are no examples of this, but in fact central bank independence on a national basis couched within a supranational political union would contain no contradictory features from an economic policy perspective - in fact it is the mirror image of the current situation in EMU, as eurozone monetary policy is operated from a supra-national level, but fiscal policy is determined in the national arena - in fact operating fiscal policy from a supra-national level but having domesticallydetermined monetary policy makes more sense from an economics standpoint, particularly when there are asymmetric shocks ${ }^{3}$. The third feature of the table shows that there is one sub-category of fiscal union (fiscal sovereignty at a supranational level) that would require at least some elemental form of political union - in other words one form of $F$ would in fact require $G$ as a pre-requisite!

The above only goes to illustrate that the Balassa stages of regional integration are only one sequencing of the various facets of what are the components of regional economic integration. But although a backwards-looking analysis of necessary preconditions for every component of Balassa's stages shows how "earlier" stages are

\footnotetext{
${ }^{2}$ If a common market is defined as an area where factors of production can freely move, then clearly the implications are different. In the EU context a common market is used interchangeably with the single market concept.

${ }^{3}$ The G7 policy initiatives of the 1980s are probably the closest we have come to an arrangement whereby fiscal policy is coordinated/integrated but coupled with monetary policy independence.
} 
usually not a pre-requisite in theory, it does not illustrate how "spillover effects", (which refer to different phenomena in political science and economics), might push any regional integration agreement towards deeper levels of integration. To a political scientist, spillover effects refer to the phenomena whereby a policy prompts policy initiatives in other areas. To an economist, spillover effects refer to the phenomena whereby "public policies in one jurisdiction necessarily have effects that significantly affect others" (quoted from Robson (1998) p125) - in economics these are often referred to as cross-border externalities. An example of a "political science" spillover effect would be the need for greater coordination of fiscal policies after the establishment of EMU as embodied by the Stability and Growth pact (SGP). An example of an "economic" spillover effect might be increased shopping in France by UK citizens because of lower excise taxes on certain goods, given the existence of the single market. Naturally, some spillover effects are both political and economic in nature, and an example of such a case might be the establishment of an EU competition policy given the existence of the single market. Despite the confusion that originates from separate development of conceptual terms in the two disciplines, both definitions imply that one level of integration might lead to another. This is explored in table 3 below.

Table 3 stresses the linkages between the stages of economic integration using spillover criteria. Combining this with the earlier analysis in table 2, it suggests that there are both backwards and forward linkages between the different types of economic integration. Figure 1 below summarises these linkages using a network map. Each "node" represents a stage of economic integration, and the arrows between each node either represent pre-conditions or spillover dynamics.

If the arrows in the figure point to an earlier stage of integration this implies conditionality on that previous level of integration, and if the arrow points to a later stage of integration, then spillover effects tend to push the regional integration project towards this later stage. Clearly if there are arrows pointing both ways between any two boxes then the former is a pre-requisite for the latter and through spillovers the former tends to promote the latter. In the context of network maps, this relationship can be termed as "mutual interdependency".

One of the striking things about the network mapping is that only in the early stage and later stages of integration is there any mutual interdependency (two way mappings). These stages are the trade integration and common market stages and the fiscal and political union stages. The analysis implies that if other stages of integration are achieved, then if sequentially this is due to spillover-type effects, 
Table 3. Possible "Spillover" Consequences of Integration

\begin{tabular}{|c|c|c|c|c|}
\hline $\begin{array}{l}\text { Level of } \\
\text { integration }\end{array}$ & Description & Spillover characteristic... & $\begin{array}{l}\text {...leads to level } \\
\text { of integration }\end{array}$ & Examples \\
\hline \multirow[t]{2}{*}{0} & $\begin{array}{l}\text { Regional } \\
\text { autarky }\end{array}$ & $\begin{array}{l}\text { - need/desire for uniformity in } \\
\text { bilateral trade agreements } \\
\text { (political/economic) }\end{array}$ & $\mathrm{B}($ or $\mathrm{A})$ & Mercosur, FTAA \\
\hline & & $\begin{array}{l}\text { - desire to reap comparative } \\
\text { advantages (economic) }\end{array}$ & A or B & NAFTA, ASEAN \\
\hline \multirow[t]{2}{*}{ A } & FTA & $\begin{array}{l}\text { - desire to reduce trade } \\
\text { deflection effects }\end{array}$ & B & NAFTA \\
\hline & & - factor price equalization & $\mathrm{C}$ & NAFTA \\
\hline \multirow[t]{2}{*}{ B } & $\begin{array}{l}\text { Customs } \\
\text { union }\end{array}$ & $\begin{array}{l}\text { - desire to reap greater factor } \\
\text { of production efficiencies }\end{array}$ & $\mathrm{C}$ & Mercosur \\
\hline & & $\begin{array}{l}\text { - desire for greater stability } \\
\text { in trade flows }\end{array}$ & $\mathrm{E}$ & SACU \\
\hline \multirow[t]{5}{*}{$\mathrm{C}$} & $\begin{array}{c}\text { Common } \\
\text { market }\end{array}$ & $\begin{array}{l}\text { - harmonization or coordination } \\
\text { of policies which affect }\end{array}$ & $\mathrm{D}$ and $\mathrm{F}$ & CEAO (West Africa), EU \\
\hline & & enterprise location/FDI & & EU \\
\hline & & - negative externalities & $\mathrm{D}$ & EU \\
\hline & & $\begin{array}{l}\text { - elimination of costs associated } \\
\text { with price supports (CAP) }\end{array}$ & $\mathrm{E}$ & \\
\hline & & $\begin{array}{l}\text {-price transparency in the } \\
\text { single market }\end{array}$ & $\mathrm{E}$ & EU \\
\hline \multirow[t]{3}{*}{$\mathrm{D}$} & $\begin{array}{l}\text { Economic } \\
\text { union }\end{array}$ & $\begin{array}{l}\text { - coordination of national } \\
\text { economic policies to avoid } \\
\text { centre/periphery effects }\end{array}$ & $\mathrm{F}$ & EU \\
\hline & & $\begin{array}{l}\text { - level playing field in } \\
\text { competition }\end{array}$ & $\mathrm{F}$ & EU, NAFTA \\
\hline & & - democratic deficit & G & EU \\
\hline \multirow[t]{2}{*}{$\mathrm{E}$} & $\begin{array}{l}\text { Monetary } \\
\text { union }\end{array}$ & $\begin{array}{l}\text { - coordination of fiscal policy } \\
\text { with single monetary policy }\end{array}$ & $\mathrm{F}$ & Ecofin, Eurogroup in EU \\
\hline & & - democratic deficit & G & EU \\
\hline \multirow[t]{2}{*}{$\mathrm{F}$} & Fiscal union & $\begin{array}{l}\text { - appropriate level of } \\
\text { provision of public services }\end{array}$ & G & Canada \\
\hline & & $\begin{array}{l}\text { - appropriate redistributive } \\
\text { mechanism }\end{array}$ & G & Germany \\
\hline
\end{tabular}

Note: $\mathrm{G}=$ political union

and if not, this is likely due to political decisions to move to a specific stage of integration.

Another interesting feature of the network mapping is that monetary and economic union do not seem to be strongly related, and yet the EU decided to package these two together in EMU. From a theoretical perspective then, there is apparently little to directly connect the two - yet a perceived direct linkage was very prominent in 
Figure 1. Network mapping of linkages between integration stages

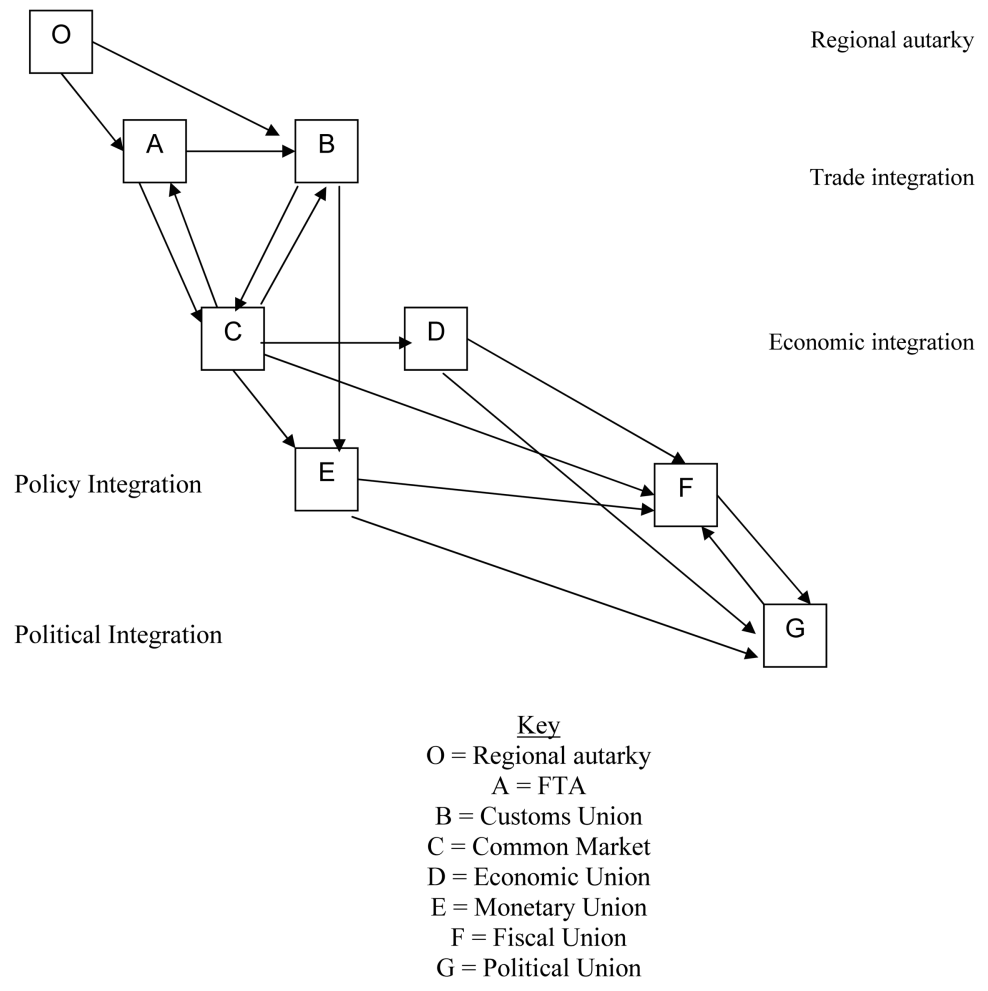

the early economics literature surrounding EMU and more recently the Stability and Growth pact literature. Criticisms of the Maastricht economic convergence criteria for EMU made by Eichengreen and Von Hagen (1995), Crowley (1996), Buiter (1998) and others forcefully made this point. Only in the minds of the designers of EMU was there a direct link between economic and monetary union ${ }^{4}$.

Before proceeding further, an important caveat is in order. Politically-motivated considerations, rather than economic considerations, can also drive the integration dynamic. In particular, the popular appeal in the political science literature to the "two-level" games framework is thought to also drive integration, as politicians seek to tie domestic policy to internationally-determined criteria. One example of this would be the way in which economic convergence was achieved according to

\footnotetext{
${ }^{4}$ In the document used by the Commission to sell EMU to finance ministers (European Commission (1990)), the Commission acknowledges (p11) this, but goes on to justify economic union on the basis of deepening the single market ("impulsion"), the threat of errant governments in terms of fiscal profligacy ("cooperation") and political expediency ("cohesion").
} 
the Maastricht criteria, which in many instances forced EU member states to follow unpopular domestic policies in order to enter EMU.

\section{Implications for the EU}

\section{A. Analysis of the EU's current state of integration}

As the EU is at an intermediate stage of integration, clearly path dependency matters in the sense that Figure 1 illustrates that there were alternative integration paths that could have been used to get to the current EU level of integration. But more importantly perhaps, it also implies that there are several options for continuing beyond the current level of economic integration.

There are two additional points that need to be made in the EU context to supplement the framework established in figure 1: first, members have been added at discrete points in time, and second, the Stability and Growth pact (SGP), which is currently in place, needs to be incorporated into this framework.

The addition of new member states, as happened with ten additional member states joining the EU in May 2004, obviously leads to a change in the median preference among the participants in the project, and explains why consensus and weighted majority voting rules still play a major role in the decisions of the EU Council. Many examples of this exist in the EU context, from the UK's obstinacy over the budget, to the emergence of a lobby group of "olive" member states from the Mediterranean regions, and the addition of CEE countries has already significantly shifted the balance of power again in EU institutions and decisionmaking. The decision to add new members changes the integration dynamic and can cause the direction of the process to shift from its original course ${ }^{5}$. It has now been clear for some time in the EU that there are a "hard core" of member states (notably Germany, Austria, the Benelux members states and France) who are keen to see a deeper level of integration achieved more rapidly. Other member states are either luke-warm towards further integration (e.g. Spain, Finland, Ireland), or are hostile to it and seek opt-outs rather than allow any significant transfer of sovereignty (e.g. Denmark, Sweden and the UK). As more member states have been added to the EU, the rate of "catch-up" with existing member states in terms of acclimatization to EMU, a common market and the political bargaining that

${ }^{5}$ For example, as de Witte (2001) notes, the German call in mid-2000 for an EU "constitutional treaty" was only met with a positive reaction by the original founding six members states of the EU. 
takes place in the EU, will likely determine the acceptability of any proposals for further integration. In fact, as the argument over voting weights in the EU Council already attested, letting further CEE countries join might create a significant voting bloc to stall future initiatives, regardless of how the integration dynamic plays out after EMU.6

The second issue relates to the SGP, which effectively broke down in early 2004, as both Germany and France managed to garner enough votes to suspend the punitive elements of the pact in order to avoid the sanctions and fines that would inevitably follow from continuing to run excessive deficits. Characterizing the SGP in the context of the stages of integration in table 1 is difficult, as the pact refers to national fiscal policies - so as the most important element of the pact (to date, at least) is the limit placed on budget deficits, it could be characterized as a substitute for the "harmonizing" element of F (fiscal union), but on the other hand it does not create any new supranational fiscal authority and nor does it harmonize taxes, so possibly could be characterised more as a particular form of $\mathrm{D}$ (economic union). Either way, economists have not really thought about what the consequences are of the breakdown in the SGP, with some now advocating completely scrapping the pact, others supporting a change in focus for the pact and yet others recommending that fiscal transfers be boosted so as to facilitate re-adoption of the pact ${ }^{7}$. Rather than engage in the debate over the future and proper purpose of the SGP, in this paper it is assumed that the pact acts as a very blunt instrument of fiscal coordination so in terms of the integration template can be categorized as economic integration.

Figure 2 illustrates the EU route through the integration stages. All regional integration projects have different initial conditions, in the form of cultural and political homogeneity - but also it was suggested above that path-dependence also exists. So what are the factors that affect which path is taken? This is a difficult question to answer satisfactorily, if at all, so here we address this by asking a somwhat different question, but one which does indirectly address the path-dependency issue. The real question countries and states need to address when moving to a specific level or type of integration, is: "What is being given up, or how are domestic policymakers hands tied by adopting this form of integration?". Table 4 attempts to provide some answers to this question.

\footnotetext{
${ }^{6}$ See Wallace (1999).

${ }^{7}$ See De Grauwe (2003), Begg and Schelkle (2004) and Collignon, S. (2003) for three different examples of these views. Buti, Eijffinger and Franco (2003) also offer some reflections on the pact and Crowley (2004) summarizes other replacements put forward for the pact in the literature.
} 
Figure 2. Scenarios for integration for the EU post-EMU

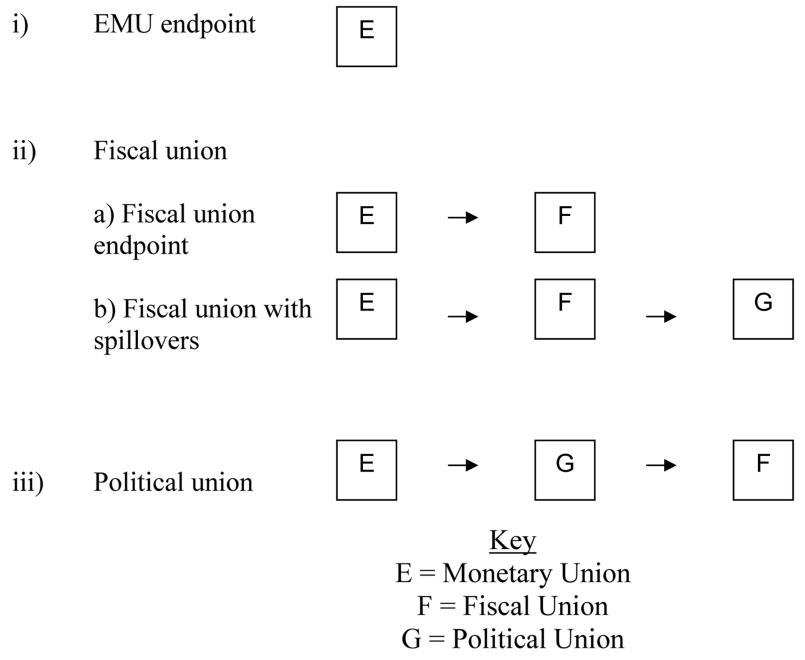

Several points arise from table 4. First, the "deeper" forms of integration (forms D, E, F and G) imply substantial loss of national autonomy, although D (economic union) appears to be least objectionable from the point of view of protection of domestic interests. This might explain why, with the notable exception of the EU, nearly all other regional trade agreements focus solely on the earlier stages of integration. Second, as Krugman (1991) makes clear, a common market would imply that specialised labour would move to the highest-paying countries instead of corporations moving to the lowest cost countries: so clearly in terms of potential economic dislocation an FTA or CU is less severe for an economy than implementing a full common market ${ }^{8}$. Third, out of $\mathrm{E}, \mathrm{F}$ and G, E (monetary union) is likely the easiest to accomplish because it gives up a policy prerogative that is usually delegated to a government agency rather than determined by political representatives. Certainly, mainstream economic literature stresses the potential inflation advantages of central bank independence and perhaps even growth advantages (- although there is less agreement on the latter claim). Lastly, although D (economic union) could conceivably operate most efficiently with supranational institutions, these are not

\footnotetext{
${ }^{8}$ Interestingly, Canada could perhaps be a good counter-example to this logic: it still does not constitute a single market, even though it is a single currency area and has a fiscal and political union. Attempts to remove inter-provincial trade barriers to protect markets such as brewing, were made by Prime Minister Mulroney as part of the Charlottetown accord in 1991, but these were rejected by a general referendum over issues relating to Quebec and the Constitution.
} 
Table 4. Implied Changes and Commitments from Integration

\begin{tabular}{|c|c|c|c|}
\hline $\begin{array}{l}\text { Level of } \\
\text { integration }\end{array}$ & Description & Initial change implied & Ongoing commitment \\
\hline $\mathrm{A}$ & FTA & $\begin{array}{l}\text { - reduction in tariffs and quotas } \\
\text { in politically sensitive areas } \\
\text { - possibility of trade diversion } \\
\text { - dislocation due to structural } \\
\text { economic changes } \\
\text { - loss of influence over } \\
\text { corporation location }\end{array}$ & $\begin{array}{l}\text { - extending to other areas such as } \\
\text { services } \\
\text { - monitoring state aid } \\
\text { - allocating resources to dispute } \\
\text { settlement boards } \\
\text { - to retain corporate competitiveness } \\
\text { - to monitor trade deflection }\end{array}$ \\
\hline B & $\begin{array}{l}\text { Customs } \\
\text { union }\end{array}$ & $\begin{array}{l}\text { - as above } \\
\text { - potential loss of income } \\
\text { for high tariff countries }\end{array}$ & - as above \\
\hline $\mathrm{C}$ & $\begin{array}{c}\text { Common } \\
\text { market }\end{array}$ & $\begin{array}{l}\text { - migration, and associated } \\
\text { factor price equalisation } \\
\text { - greater capital mobility/ } \\
\text { instability }\end{array}$ & - oversight of fair competition \\
\hline $\mathrm{D}$ & $\begin{array}{l}\text { Economic } \\
\text { union }\end{array}$ & $\begin{array}{l}\text { - consultation where } \\
\text { coordination is concerned } \\
\text { - changes to domestic policies } \\
\text { where harmonization is } \\
\text { concerned } \\
\text { - loss of national jusrisdiction/ } \\
\text { administration (cost savings) } \\
\text { where supranational transfer is } \\
\text { concerned }\end{array}$ & $\begin{array}{l}\text { - compliance with agreements over } \\
\text { coordination/supranational transfer } \\
\text { - reporting requirements }\end{array}$ \\
\hline $\mathrm{E}$ & $\begin{array}{l}\text { Monetary } \\
\text { union }\end{array}$ & $\begin{array}{l}\text { - loss of exchange rate policy } \\
\text { - loss of independent monetary } \\
\text { policy }\end{array}$ & $\begin{array}{l}\text { - trade gains } \\
\text { - reporting requirements }\end{array}$ \\
\hline $\mathrm{F}$ & $\begin{array}{l}\text { Fiscal } \\
\text { union }\end{array}$ & $\begin{array}{l}\text { - loss of independent fiscal } \\
\text { policy } \\
\text { - loss of "low tax" status }\end{array}$ & - reporting requirements \\
\hline G & $\begin{array}{c}\text { Political } \\
\text { union }\end{array}$ & $\begin{array}{l}\text { - loss/subjugation of } \\
\text { independent political } \\
\text { framework for policy-making } \\
\text { - smaller state bureaucracy } \\
\text { - dual representation }\end{array}$ & $\begin{array}{l}\text { - more complicated electoral system } \\
\text { - delineation of federal vs state } \\
\text { responsibilities }\end{array}$ \\
\hline
\end{tabular}

necessary for its effective operation, whereas for E, F and G, supranational institutions would likely be necessary. As national governments have a certain reticence about establishing supranational institutions because of "political" spillover, these stages will probably be deemed less palatable to most national governments. A good example of this logic might be the SGP (see Artis and Winkler (1997) and Crowley (2001)). Here a potential spillover from E to F was recognised but a way 
was found to avoid constructing a supranational institution by agreeing on a pact to coordinate fiscal policy.

Although recognition of spillovers clearly gives rise to certain policy problems in this context (for example, how to enforce the SGP), non-recognition can be equally problematic. An example of this might be the problem of the asymmetry surrounding the arrangements for the ECB, given that it effectively has no single democratic institution to be accountable to (see Crowley and Rowley (1998) for a description as to possible solutions to this problem, and see Buiter (1998) and Haan and Eijfinger (2000) for extensive discussions on ECB accountability).

To summarise, in comparative terms within the context of the stages of regional integration, the above reasons go a long way towards explaining i) why most of the regional integration agreements in the world are FTAs or CUs, ii) why fiscal, monetary and political union are not seen as desirable to many countries, and iii) why if one of ii) has to be chosen, then monetary union would most likely be least problematic (particularly for countries that already operate with independent central banks), and easiest to achieve politically.

\section{B. The EU: What next?}

Having completed EMU and the expansion from 15 member states to 25, the $\mathrm{EU}$ is now looking to further expand and also to the possibility of further integration between existing members ${ }^{9}$. Marrying these two institutional forces on a stable trajectory is a challenging task, as clearly the two dynamics are to a certain degree interdependent. The questions then become: what effect will EMU and the CEEC expansion have on the EU integration dynamic, and what is the need for further integration? Further, is there any logical sequence for further integration?

Taking the extended Balassa template given that EMU has been successfully achieved, figure 1 points to fiscal or political union as the next obvious stages of integration. But what about sequence? Belassa's schema implies that fiscal union should occur first, but figure 1 suggests there are actually three possible routes:

i) EMU endpoint: EU integration ends at EMU and although there are some efforts to coordinate and harmonize some aspects of fiscal policy, fiscal policy independence is largely retained by member states, perhaps with a modified SGP or by scrapping the SGP (see Crowley (2004));

\footnotetext{
${ }^{9}$ The recent agreement in 2004 on a draft Constitution for the EU is one example of a continuing integration dynamic. Others include the European Defence Initiative and a strengthening of the Broad Economic Guidelines.
} 
ii) Fiscal union: move to fiscal union (F), and then there are two possibilities - a) either a weaker version of the SGP is maintained ${ }^{10}$, and fiscal coordination and harmonisation become the "finality" of the EU integration process, and b) that due to spillovers, fiscal union leads to political union $(G)$.

iii) Political union: a move directly to political union $(\mathrm{G})$, by giving the European parliament more powers and perhaps (following suggestions by Joschka Fischer and Tony Blair that were incorporated in the Treaty of Nice) the incorporation of national parliament representatives in a second EU chamber, which would grant more legitimacy to supranational democracy. Following political union, figure 1 suggests that supranational fiscal sovereignty could be acquired through this route, as politicians would demand some fiscal powers so as to be effective policymakers.

Figure 2 illustrates the three possible outcomes for integration within the EU given that EMU is successful. The diagram illustrates that if fiscal union is blocked by member states, but there is a possibility for some degree of political union, then this (option iii) above) may be the best way to achieve fiscal union in the long run, as a legitimate political union should then be able to acquire fiscal responsibilities at a supranational level much more easily than by using the usual Balassa stages of integration, which would imply following option ii) above (see Wessels (1997) for more on the political implications of EMU).

There has been little research on further integration after EMU, and the only paper that directly addresses the issue is Costa and De Grauwe (1999). Costa and De Grauwe take a much narrower view of the integration process beyond EMU and focus on the political "spillovers" as well as single market issues that will arise after EMU implementation. They analyse labour mobility, tax harmonisation, industrial location, transportation and legislation regarding takeovers as possible areas where EMU will put further pressure for integration or at least harmonisation or cooperation. Here industrial location and associated agglomeration effects, as well as legislation regarding takeovers will be put aside, because they largely fall under the rubric of single market issues. Transportation is certainly important and with the single market it is clearly becoming imperative to have at minimum harmonisation of national standards under some umbrella EU transport policy - but again this comes under the rubric of economic union - an integration initiative that is ongoing. So this leaves labour mobility and tax harmonisation. Labour mobility also comes under the rubric for the single market, the EU version of a common market, but neverthe-

\footnotetext{
${ }^{10}$ One formulation might be to have balanced budget rules for member states - see Crowley (2004).
} 
less does have an important interrelationship with EMU so like tax harmonisation is considered below.

According to the originally proposed theory of optimum currency areas (developed by Mundell (1961), Kenen (1969) and McKinnon (1969)), labour mobility is important if a single currency area is not optimal (see De Grauwe (1992), Bayoumi and Eichengreen (1993, 1994), Bayoumi (1994), Artis and Zhang (1997), LaFrance and St-Amant (1999) for a detailed review of the OCA literature and Björksten and Syrjänen (2000)) - certainly this is an important element in ensuring that the US largely remains an $\mathrm{OCA}^{11}$. What is the evidence about labour mobility in the EU? The evidence is that labour mobility in the periphery is greater than in the "core", so in a sense this does bode well given that agglomeration effects should eventually lead to more activity in the core. Also further evidence suggests that low-skilled labour mobility in the core is much lower than high-skilled labour mobility - the economic rationale being social security ${ }^{12}$. As taxes fall on income of low-skilled labour in the core, this should increase net wages and prompt an increase in labour mobility, but there is significant resistance to this process, so it may take some time to occur, and will likely never reach US or Canadian levels because of cultural and linguistic barriers.

On the other hand, EMU might turn out to be optimal ex-post, as Frankel and Rose (1997) have pointed out ${ }^{13}$. Indeed, the original research on the tendency for monetary unions to promote greater trade between its members (see Rose (2000) and Rose (2001) for the seminal articles) has spawned an extensive literature, but still there are considerable doubts within the economics profession that the trade effects are as large as some suggest ${ }^{14}$. Another strand of the literature suggests that business cycle asynchronicity might "naturally" be reduced by EMU membership

\footnotetext{
${ }^{11}$ The referee for this article pointed out that greater labour market flexibility might substitute for labour mobility in the EU. Although there appears to be the emergence of a trend towards greater flexibility in EU labour markets, most economic commentators agree that the EU falls far behind the US or Canada. It could also be argued that labour market flexibility could likely counteract small asymmetries or asymmetric shocks, but would be a poor substitute for labour mobility in the face of large regional asymmetries or shocks.

${ }^{12}$ Social security in the core countries is very well developed and eliminates any financial incentives for low-skilled labour to move.

${ }^{13}$ Economists usually refer to an optimal currency area (OCA) that occurs ex-post as an endogenous OCA

${ }^{14}$ Baxter and Kouparitsas (2004) suggest that in fact trade has no "robust" impact on business cycle propagation, so implying that trade is unlikely to promote endogenous OCAs.
} 
as EMU might foster a stronger European business cycle (see Artis and Zhang (1997), Inklaar and De Haan (2001), and Artis, Krolzig and Toro (2004)). Although Artis and Zhang (1997) base their arguments on the ERM of the EMS being a form of monetary coordination, which in turn induced greater asynchronicity, most economists would likely argue that it is likely too early to judge whether the degree of asynchronicity has really fallen, as the eurozone member states have yet to go through even one complete business cycle in EMU.

So let us suppose that EMU becomes an endogenous OCA - then is the pattern of follow-through integration dependent on the circumstances that engendered this endogeneity? First, take labour mobility. If labour becomes more mobile in the EU then fiscal issues will be of prime concern - ensuring social security contributions and pension contributions are portable - plus harmonization of tax systems. If these issues become crucial for the success of EMU, then figure 2 above suggests that integration dynamic ii) is most likely - although it is still not clear whether option a) or b) would prevail. In terms of labour-mobility-induced fiscal harmonisation, Costa and De Grauwe (1999) make the point that taxation on very mobile taxable items will be much more likely to be harmonised or coordinated than taxation on a less mobile tax base ${ }^{15}$. This harmonisation will also likely lead to tax competition on mobile factors but less competition and therefore an array of different rates (and public service offerings) on less mobile factors ${ }^{16}$. This analysis points to little cooperation or harmonisation on income taxes and withholding taxes, but more pressure to harmonise and maybe set a common rate for VAT and corporation taxes. In terms of our analysis above in figure 3 , this fits in with integration dynamic ii) again.

If the eurozone becomes an endogenous OCA through more synchronous business cycles, then this doesn't support the integration dynamic following scenario ii) above, as there will be less necessity to take any measures on a supra-national basis in the fiscal arena. In this case, the achievement of an endogenous OCA would suggest either scenarios i) or iii) as either member state governments will decide to retain their sovereignty over existing economic and political policy areas, or the success of EMU will engender a push to correct the "democratic deficit" referred to

\footnotetext{
${ }^{15}$ Or to quote Costa and De Grauwe (1999), "the pressure to harmonise tax rates increases with the mobility of the good and the factor that is taxed" (pp35).

${ }^{16}$ Costa and De Grauwe claim this could lead to lower taxes on capital and higher taxes on labour, but do not offer any evidence for this. Clearly Tiebout factors will also come into play.
} 
earlier, implying scenario iii) as most likely. Putting this another way, an economically successful EMU might permit less resistance to a separate political integration dynamic to further transfer political powers to a directly elected European Parliament.

If the eurozone does not become an endogenous OCA, then this is most likely to prompt a move to a "stronger" form of fiscal union for the eurozone members perhaps as a separate subset of the EU member states. Clearly though, there needs to be some form of crisis in the eurozone such that monetary policy is deemed entirely inappropriate for certain member states before a supranational institution is established, and further there will be significant resistance to such initiatives from certain member states ( - and particularly those still outside the eurozone). Given this scenario it would be hard to imagine that the EU as a whole would then countenance further economic integration to the political union level of integration.

The crux of the issue surrounding the integration dynamic outlined above is that in fact a successful EMU points to only weak integration beyond EMU in the fiscal area - in other words the political "spillovers" are not likely to cause a fiscal union where policy responsibilities are transferred to a supranational level ${ }^{17}$. Further, in terms of the integration dynamic, if there is a weak form of fiscal union in the form of tax harmonization, this will likely lead to the "finality" of integration in the EU without any further tendency towards political union. An integration dynamic that is institutional in scope embracing the notion of political union before fiscal union will be much more likely to lead to the "strong" form of fiscal union that encompasses fiscal sovereignty at the supranational level. This has been directly related to whether EMU becomes an endogenous OCA - if it does, then unless a separate initiative for political union is launched, the integration dynamic alone is more likely to suggest the "weaker" form of fiscal union rather than political union - if it does not, then the integration dynamic is more suggestive that a "stronger" form of fiscal union could follow - either directly, or indirectly via political union. Of course the irony here is that if the eurozone is an endogenous OCA this tends to halt the integration dynamic, whereas if the eurozone is not an endogenous OCA then this will likely resuscitate the integration dynamic.

Lastly we turn to the role of the SGP in this dynamic. Despite its recent topicality,

\footnotetext{
${ }^{17}$ During the 2001 UK general election campaign, Frits Bolkestein, the EU internal market commissioner declared that "harmonisation of income taxes is out". A few days later similar gestures were made by Tony Blair, UK Prime Minister, with regard to corporation taxes in response to suggestions by French Prime Minister Jospin that taxes in the EU should be harmonised.
} 
its role here is rather unclear. Only in a "stonger" form of fiscal union does the SGP possess a real role, as its coercive elements clearly act as an agreement to limit member state deficits. Another view is that the SGP might be seen as a stepping stone to much deeper levels of integration, much in the same way that the benefit of hindsight leads us to conclude that the ERM of the EMS was a stepping stone to EMU.

\section{Conclusions}

In this paper, the Balassa stages of economic integration were reviewed and analysed from an economic and political perspective. The implied sequence of integration was also placed in the context of the liberalisation of the world trading system, and examples were given of regional integration projects and different integration dynamics. The Balassa framework was found to be useful but flawed from a dynamic perspective, and an updated taxonomy was developed which encompasses a variety of integration dynamics.

The sequence of economic integration was analysed using two different approaches a backward-looking economic conditionality approach, where each stage of the integration was conditioned on other stages - and a forward-looking politicoeconomic spillover approach which looked at which further stage(s) of integration are suggested at any specific stage of integration. Although some comparisons were then made between the economic integration projects that exist today, the main focus of the paper was on the development of the EU and what should come after EMU nothing, fiscal integration, political integration, or a combination of both.

The framework used to link the different stages of economic integration was applied to the EU, given a successful implementation of EMU. The analysis uncovered three possible broad scenarios, all with different implications for the endpoint of the integration dynamic in the EU. One finding was that there is little economic impetus behind the economic integration dynamic beyond monetary union if the eurozone becomes an OCA. A second finding was that there is no logical reason why fiscal union needs to occur directly after EMU - the alternative being a dynamic that pushes for political union first and then this could subsequently legitimate fiscal sovereignty at a supranational level.

\section{Acknowlegments}

Any of the revisions to this paper were done while at the Bank of Finland during 
academic 2004/2005. I would like thank the Bank for their hospitality and generously making their facilities and resources available.

Received 31 July 2003, Accepted 19 April 2005

\section{References}

Artis, M. and Winkler, B. (1997), "The Stability Pact: Safeguarding the Credibility of the European Central Bank", CEPR Discussion Paper 1688, CEPR, London, UK.

Artis, M. and Zhang, W. (1997), "International Business Cycles and the ERM: Is there a European Business Cycle?", International Journal of Finance and Economics, 2, 1-16.

Artis, M., Krolzig, H-M., Toro, J. (2004), "The European Business Cycle”, Oxford Economic Papers, 56, 1-44.

Balassa, R. (1961), The Theory of Economic Integration, Irwin, Homewood, USA.

Baxter, M. and Kouparitsas, M. (2004), "Determinants of Business Cycle Comovement: A Robust Analysis", NBER Working Paper 10725, Cambridge, USA

Bayoumi, T. (1994), "A Formal Model of Optimum Currency Areas", IMF Staff Papers, 41(4), 537-554.

Bayoumi, T. and Eichengreen, B. (1993), "Shocking Aspects of European Monetary Unification", in Giavazzi, F. and Torres, F., Adjustment and Growth in the European Monetary Union, Cambridge University Press, Cambridge, UK.

Bayoumi, T. and Eichengreen, B. (1994), "One Money or Many?: Analyzing the Prospects for Monetary Unification in Various Parts of the World", Princeton Studies in International Finance 76, Princeton University, USA.

Begg, I. and Schelkle, W. (2004), "The Pact is Dead: Long Live the Pact", National Institute Economic Review, No 189, London, UK.

Björksten, N. and Syrjänen, M. (2000), "How Problematic are Internal Euro Area Differences?", EUI Working Papers, RSC 2000/14.

Buiter, W. (1998), "The Economic Case for Monetary Union in the European Union", Review of International Economics, 5(4S), 10-35.

Buti, M., Eijffinger, S. and Franco, D. (2003), "Revisiting EMU's Stability Pact: A Pragmatic Way Forward", Oxford Review of Economic Policy, 19(1), 100-111.

Collignon, S. (2003), "Is Europe going far enough? Reflections on the EU's economic governance", European Political Economy Review, 1(2), 222-247.

Costa, C. and De Grauwe, P. (1999), "EMU and the Need for Further Economic Integration", in Meeusen, W. (ed), Economic Policy in the European Union, Edward Elgar, Cheltenham, UK, 27-48.

Crowley, P. (1996), "EMU, Maastricht and the 1996 IGC", Contemporary Economic Policy, XIV(2), pp41-55.

Crowley, P. (2001), "The Institutional Implications of EMU”, Journal of Common Market Studies, 39(3), 385-404. 
Crowley, P. (2004), "Stability and Growth Pact: Intermission, Comedy or Tragedy?", Paper presented at UACES Conference, University of Birmingham, UK, September.

Crowley, P. and Rowley, R. (1998), "European Integration and Monetary Unification: Configurations, Fiscal and Monetary Policy Design and Institutional Development", Journal of European Integration, XXI(3), 203-229.

De Grauwe, P. (1992), The Economics of Monetary Integration, Oxford University Press, Oxford, UK.

De Grauwe, P. (2003), "The Stability and Growth pact in need of reform", Unpublished manuscript, University of Leuven, Belgium.

De Witte, B. (2001), “Après Nice: Time for European Constitution?", ECSA Review, Spring, 10-11.

Eichengreen, B. and von Hagen, J. (1995), "Fiscal Policy and Monetary Union: Federalism, Fiscal Restrictions and the No-bailout Rule", CEPR Discussion Paper 1247, CEPR, London, UK.

European Commission (1990), "Economic and Monetary Union: The Economic Rationale and Design of the System", Working Document of the Commission, Presented to Finance Ministers, March 31- April, 1990, Brussels, Belgium

Frankel, J. and Rose, A. (1997), "Is EMU more justifiable ex post than ex ante?", European Economic Review 41, 753-760.

Haan, J. de, and Eijffinger, S. (2000), "The Democratic Accountability of the European Central Bank", Journal of Common Market Studies, 38(3), 393-408.

Kenen, P. (1969), "The Theory of Optimal Currency Areas: An Eclectic View", in (eds), Mundell, R. and A. Swoboda, Monetary Problems of the International Economy, University of Chicago Press, Chicago, USA.

Krugman, P. (1991), Geography and Trade, MIT Press, Cambridge, USA.

Laffan, B., O’Donnell, R. and Smith, M. (2000), Europe's Experimental Union, Routledge, London, UK.

LaFrance, R. and St-Amant, P. (1999), "Optimum Currency Areas: A Reviews of the Recent Literature", Bank of Canada Working Paper 99-16.

McKinnon, R. (1969), "Optimum Currency Areas”, American Economic Review, 53, 717- 55.

Molle, W. (1997), The Economics of European Integration, Ch 2 (Basic Concepts and Structures), Ashgate.

Mundell, R. (1961), "A Theory of Optimum Currency Areas", American Economic Review, 51, 657-675.

Robson, P. (1998), The Economics of International Integration, Fourth edition, Routledge, London, UK.

Wallace, H. (1999), "Whose Europe is it anyway?", European Journal of Political Research, 35, 287-306.

Wessels W., (1997), “An ever closer union? A dynamic macro-political view on integration processes", Journal of Common Market Studies, 35(2), 267-99. 